Article

\title{
Resveratrol Downregulates Granulocyte-Macrophage Colony-Stimulating Factor-Induced Oncostatin M Production through Blocking of PI3K/Akt/NF-kB Signal Cascade in Neutrophil-like Differentiated HL-60 Cells
}

\author{
Na-Ra Han ${ }^{1,2}$, Hi-Joon Park ${ }^{3}$ and Phil-Dong Moon ${ }^{4, *}$ \\ 1 College of Korean Medicine, Kyung Hee University, Seoul 02447, Korea; nrhan@khu.ac.kr \\ 2 Korean Medicine-Based Drug Repositioning Cancer Research Center, College of Korean Medicine, \\ Kyung Hee University, Seoul 02447, Korea \\ 3 Department of Anatomy \& Information Sciences, College of Korean Medicine, Kyung Hee University, \\ Seoul 02447, Korea; acufind@khu.ac.kr \\ 4 Center for Converging Humanities, Kyung Hee University, Seoul 02447, Korea \\ * Correspondence: pdmoon@khu.ac.kr; Tel.: +82-2-961-0897
}

check for updates

Citation: Han, N.-R.; Park, H.-J.; Moon, P.-D. Resveratrol Downregulates Granulocyte-Macrophage Colony-Stimulating Factor-Induced Oncostatin M Production through Blocking of PI3K/Akt/NF- $k$ B Signal Cascade in Neutrophil-like Differentiated HL-60 Cells. Curr. Issues Mol. Biol. 2022, 44, 541-549. https://doi.org/10.3390/ cimb44020037

Academic Editors: Julius Liobikas and Vidmantas Bendokas

Received: 27 December 2021

Accepted: 20 January 2022

Published: 22 January 2022

Publisher's Note: MDPI stays neutral with regard to jurisdictional claims in published maps and institutional affiliations.

Copyright: () 2022 by the authors. Licensee MDPI, Basel, Switzerland. This article is an open access article distributed under the terms and conditions of the Creative Commons Attribution (CC BY) license (https:/ / creativecommons.org/licenses/by/ $4.0 /)$.

\begin{abstract}
Oncostatin M (OSM) is essential in a wide range of inflammatory responses, and most OSM is produced by neutrophils in respiratory diseases. While resveratrol (RES) is regarded as an anti-inflammatory agent in a variety of conditions, the mechanism of OSM inhibition by RES in neutrophils remains to be elucidated. In this study, we investigated whether RES could inhibit OSM production in neutrophil-like differentiated (d)HL-60 cells. The effects of RES were measured by means of an enzyme-linked immunosorbent assay, real-time polymerase chain reaction, and Western blotting. Increases in production and mRNA expression of OSM resulted from the addition of granulocyte-macrophage colony-stimulating factor (GM-CSF) in neutrophil-like dHL-60 cells; however, these increases were downregulated by RES treatment. Exposure to GM-CSF led to elevations of phosphorylation of phosphatidylinositol 3-kinase (PI3K), Akt, and nuclear factor (NF)$\mathrm{kB}$. Treatment with RES induced downregulation of the phosphorylated levels of PI3K, Akt, and NF- $\mathrm{KB}$ in neutrophil-like dHL-60 cells. These results suggest that RES could be applicable to prevent and/or treat inflammatory disorders through blockade of OSM.
\end{abstract}

Keywords: oncostatin M; resveratrol; neutrophil-like differentiated HL-60 cells; PI3K; Akt; NF-кB

\section{Introduction}

Oncostatin M (OSM) is known as a cancer-associated cytokine that is highly expressed in patients with tumors [1,2]. OSM is a member of the interleukin (IL)-6 family cytokines, and is released from a variety of cells, including macrophages, dendritic cells, activated T lymphocytes, monocytes, and neutrophils [3-5]. Cytokine OSM plays a role in various pathophysiologic conditions, such as cancer progression, extracellular matrix reconstruction, hemopoiesis, liver regeneration, heart remodeling, and inflammatory reactions [2,6-9]. OSM plays a role in a wide range of inflammatory responses [2]. Inflammatory reactions in joint disease and hepatic disease involve OSM $[2,10]$. In addition, OSM is involved in respiratory inflammatory disorders, including allergic rhinitis and asthma [11,12]. Treatment with OSM protein enhanced inflammatory responses in human intestinal stromal cell line CCD-18Co cells [3]. It was reported that OSM stimulation elevates inflammatory reactions in human keratinocyte cell line HaCaT cells [13]. Our previous report also suggested that recombinant OSM treatment upregulates inflammatory cytokine IL-1 $\beta$ production, indicating a contribution of OSM to inflammatory reactions [14]. Pothoven and colleagues [12] suggested that OSM is produced mainly in neutrophils in respiratory inflammatory disorders. However, there are no reports that provide a mechanism for OSM 
inhibition by resveratrol (RES) in neutrophils. Hence, we examined whether RES inhibits OSM expression in neutrophil-like differentiated (d)HL-60 cells.

It was widely known that phosphatidylinositol 3-kinase (PI3K) is important in regulating a variety of intracellular signaling processes [15]. Akt is a downstream kinase of $\mathrm{PI} 3 \mathrm{~K}$, and responsible for inflammatory responses [16]. It is believed that the PI3K/Akt signaling pathway is critical in triggering and amplifying the cytokine system [17]. Lv and colleagues [18] suggested that the PI3K/AKT signal cascade is regarded as a crucial factor in the treatment of various disorders, such as tumorigenesis, cardiovascular problems, and inflammatory reactions. Activated Akt induced the activation of nuclear factor (NF)- $\mathrm{kB}$ (a downstream molecule of Akt) [17]. It is known that NF-kB plays an important role as a transcription factor in chronic inflammatory reactions [19]. Su et al. [19] reported that $\mathrm{PI} 3 \mathrm{~K} / \mathrm{Akt} / \mathrm{NF}-\mathrm{KB}$ signaling pathways are involved in OSM expression in osteoblasts.

Resveratrol (RES, Figure 1) is a well-known dietary polyphenolic compound found in numerous plant species, including peanuts, grapes, mulberry, pines, apples, knotweed, blueberries, and plums $[20,21]$. RES is beneficial to human health because of its various biological properties, such as anti-cardiovascular, anti-oxidant, anti-obesity, anti-diabetic, antiinflammatory, anti-viral, neuroprotective, anti-microbial, and anti-cancer effects [21-25]. However, the effect of RES on OSM expression has not been fully clarified. We thus investigated whether RES could inhibit OSM expression in neutrophil-like dHL-60 cells.<smiles>Oc1ccc(/C=C/c2cc(O)cc(O)c2)cc1</smiles>

Figure 1. Chemical structure of resveratrol.

\section{Materials and Methods}

\subsection{Materials}

RES $\left(\mathrm{C}_{14} \mathrm{H}_{12} \mathrm{O}_{3}\right)$ was purchased from Sigma-Aldrich Inc. (St. Louis, MO, USA). OSM antibodies and granulocyte-macrophage colony-stimulating factor (GM-CSF) were purchased from R\&D Systems (Minneapolis, MN, USA). In Western blotting, phosphorylated (p)-PI3K p85 was purchased from Cell Signaling Technology (Danvers, MA, USA), and the others were purchased from Santa Cruz Biotechnology (Santa Cruz, CA, USA).

\subsection{Cells}

HL-60 cells were cultured in RPMI 1640 (Gibco BRL, Grand Island, NY, USA) containing $10 \%(v / v)$ heat-inactivated fetal bovine serum (FBS) (Welgene, Daegu, Korea), $100 \mathrm{IU} / \mathrm{mL}$ penicillin, and $100 \mu \mathrm{g} / \mathrm{mL}$ streptomycin. To prepare the neutrophilic phenotype dHL-60 cells, HL-60 cells were incubated with 1.3\% DMSO for 7 days. A total of $5 \mathrm{ng} / \mathrm{mL}$ of recombinant human GM-CSF was used to stimulate the cells, considering the reports of Elbjeirami et al. [26] and Han et al. [14].

\subsection{Cytotoxicity}

dHL-60 cells $\left(1 \times 10^{5}\right)$ were exposed to RES or PBS for $1 \mathrm{~h}$ and incubated with $5 \mathrm{ng} / \mathrm{mL}$ of GM-CSF for $4 \mathrm{~h}$. The cytotoxicity was examined as previously described [27-30].

\subsection{OSM Assay}

dHL-60 cells $\left(5 \times 10^{5}\right)$ were exposed to RES or PBS for $1 \mathrm{~h}$ and incubated with $5 \mathrm{ng} / \mathrm{mL}$ of GM-CSF for $4 \mathrm{~h}$. OSM levels were measured using an enzyme-linked immunosorbent assay, as previously described [31-34]. 


\subsection{Real-Time Polymerase Chain Reaction (PCR)}

dHL-60 cells $\left(1 \times 10^{6}\right)$ were exposed to RES or PBS for $1 \mathrm{~h}$ and incubated with $5 \mathrm{ng} / \mathrm{mL}$ of GM-CSF for $1 \mathrm{~h}$. Real-time PCR was conducted as previously described [35-38].

\subsection{Western Blotting}

dHL-60 cells $\left(5 \times 10^{6}\right)$ were exposed to RES or PBS for $1 \mathrm{~h}$ and incubated with $5 \mathrm{ng} / \mathrm{mL}$ of GM-CSF for $15 \mathrm{~min}(\mathrm{PI} 3 \mathrm{~K})$ or $30 \mathrm{~min}(\mathrm{Akt})$ or $1 \mathrm{~h}(\mathrm{NF}-\mathrm{kB})$. Western blotting was performed, as previously described [39-42].

\subsection{Statistical Analysis}

One-way ANOVA, followed by the Tukey post hoc test and independent $t$-test, was utilized to analyze the statistically significant differences between the means (IBM SPSS Statistics version 25, Armonk, NY, USA). The statistical significance was set at $p<0.05$.

\section{Results}

\subsection{RES Decreases OSM Production in Neutrophil-like dHL-60 Cells}

To investigate whether RES decreases the OSM production in neutrophil-like dHL-60 cells, we added RES into the cells $1 \mathrm{~h}$ before GM-CSF treatment. Similar to a previous report [14], increased OSM production resulted from GM-CSF treatment for $4 \mathrm{~h}$ (Figure 2a). The addition of RES led to decreased OSM production (Figure 2a). OSM production levels at concentrations of 0.03 to $3 \mu \mathrm{M}$ were $33.192 \pm 1.442,31.077 \pm 0.782$, and $30.305 \pm 0.752$, respectively (Figure 2a). OSM levels in the control and blank groups were $35.148 \pm 0.961$ and $24.172 \pm 0.642$, respectively. Cytotoxicity was not shown by the addition of RES (Figure 2b). RES alone did not affect OSM production (Figure S1a).

(a)

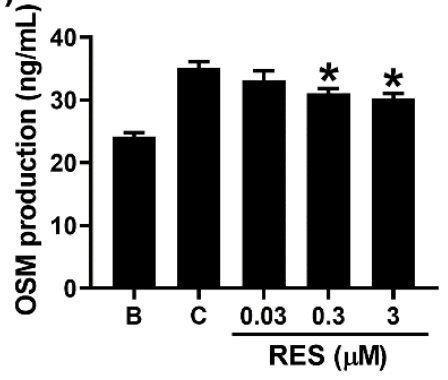

(b)

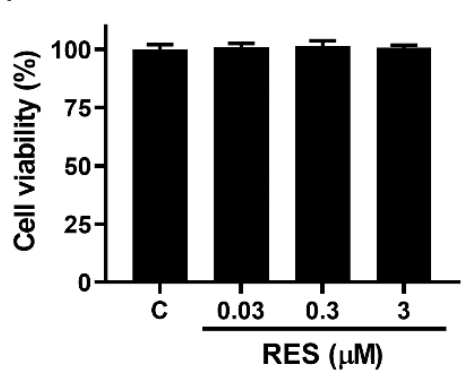

Figure 2. Effects of RES on the production of OSM in neutrophil-like dHL-60 cells. (a) dHL-60 cells $\left(5 \times 10^{5}\right)$ were exposed to RES $(0.03$ to $3 \mu \mathrm{M})$ for $1 \mathrm{~h}$, and then stimulated with GM-CSF $(5 \mathrm{ng} / \mathrm{mL})$ for 4 h. (b) Cytotoxicity was examined using an MTT assay. B, PBS-added and unstimulated cells; C, PBS-added and GM-CSF-stimulated cells. Data are shown as the mean $\pm \mathrm{SEM}$ of three independent experiments. ${ }^{*} p<0.05$ vs. the PBS-added, and GM-CSF-stimulated cells.

\subsection{RES Reducs OSM mRNA Expression in Neutrophil-like dHL-60 Cells}

To evaluate whether RES reduces OSM mRNA expression in neutrophil-like dHL-60 cells, we added RES into the cells $1 \mathrm{~h}$ before GM-CSF treatment. Similar to a previous report [14], GM-CSF treatment for $1 \mathrm{~h}$ resulted in elevated OSM mRNA expression (Figure 3). The addition of RES led to reduced OSM mRNA expression (Figure 3). The relative levels of OSM mRNA, at concentrations of 0.03 to $3 \mu \mathrm{M}$, were $0.547 \pm 0.027,0.461 \pm 0.015$, and $0.424 \pm 0.013$, respectively. The levels in the control and blank groups were $0.568 \pm 0.021$ and $0.311 \pm 0.013$, respectively. We examined the regulatory effect of $3 \mu \mathrm{M}$ of RES in the subsequent experiment (Western blotting), because the effect of $3 \mu \mathrm{M}$ of RES was greater than those of 0.03 and $0.3 \mu \mathrm{M}$. RES alone did not affect OSM mRNA expression (Figure S1b). 


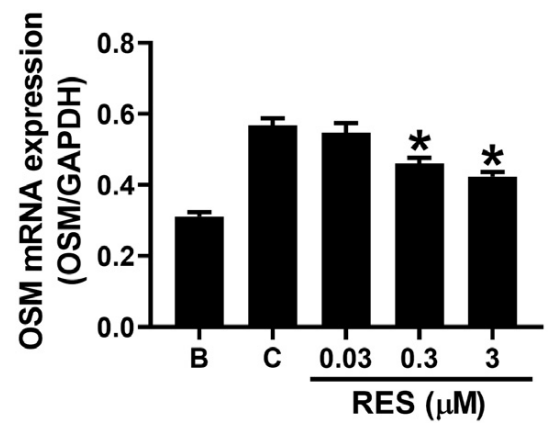

Figure 3. Effects of RES on the mRNA expression of OSM in neutrophil-like dHL-60 cells. dHL60 cells $\left(1 \times 10^{6}\right)$ were exposed to RES $(0.03$ to $3 \mu \mathrm{M})$ for $1 \mathrm{~h}$, and then stimulated with GM-CSF $(5 \mathrm{ng} / \mathrm{mL})$ for $1 \mathrm{~h}$. B, PBS-treated and unstimulated cells; C, PBS-treated and GM-CSF-stimulated cells. B, PBS-added and unstimulated cells; C, PBS-added and GM-CSF-stimulated cells. Data are shown as the mean \pm SEM of three independent experiments. ${ }^{*} p<0.05$ vs. the PBS-added and GM-CSF-stimulated cells.

\subsection{RES Downregulates Phosphorylation of PI3K in Neutrophil-like dHL-60 Cells}

To understand the regulatory mechanism of OSM reduction by RES, we exposed neutrophil-like dHL-60 cells to RES $(3 \mu \mathrm{M})$ for $1 \mathrm{~h}$. Similar to a previous report [14], GMCSF treatment for $15 \mathrm{~min}$ induced upregulated PI3K phosphorylation (Figure 4). However, the exposure to RES resulted in downregulation of PI3K phosphorylation (Figure 4). RES alone did not affect PI3K phosphorylation (Figure S2a,b).

(a)

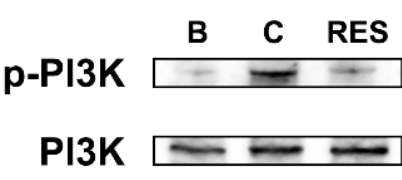

(b)

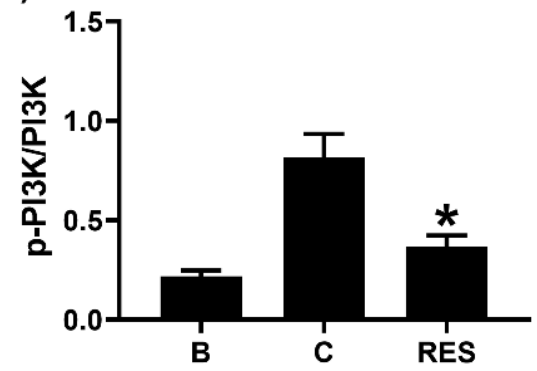

Figure 4. Effects of RES on the phosphorylation of PI3K in neutrophil-like dHL-60 cells. (a) dHL-60 cells $\left(5 \times 10^{6}\right)$ were exposed to RES $(3 \mu \mathrm{M})$ for $1 \mathrm{~h}$, and then stimulated with GM-CSF $(5 \mathrm{ng} / \mathrm{mL})$ for $15 \mathrm{~min}$. (b) The protein levels were quantitated by densitometry. B, PBS-added and unstimulated cells; C, PBS-added and GM-CSF-stimulated cells; RES, RES-added and GM-CSF-stimulated cells. Data are shown as the mean \pm SEM of three independent experiments. ${ }^{*} p<0.05$ vs. the PBS-added and GM-CSF-stimulated cells.

\subsection{RES Inhibits Phosphorylation of Akt in Neutrophil-like dHL-60 Cells}

To examine the regulatory mechanism of OSM reduction by RES, we exposed neutrophillike dHL-60 cells to RES ( $3 \mu \mathrm{M})$ for $1 \mathrm{~h}$. Similar to a previous report [14], GM-CSF treatment for $30 \mathrm{~min}$ induced elevated Akt phosphorylation (Figure 5). However, the exposure to RES resulted in decreased phosphorylation of Akt (Figure 5). RES alone did not affect Akt phosphorylation (Figure S2c,d). 
(a)

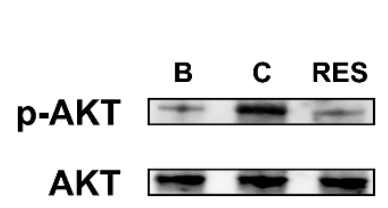

(b)

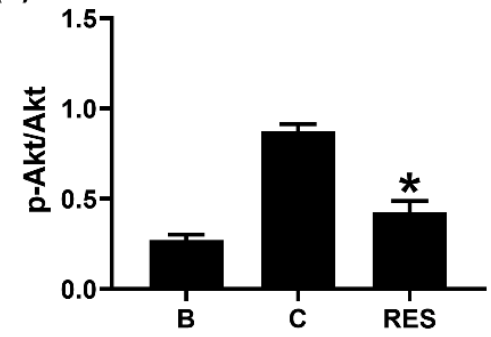

Figure 5. Effects of RES on the phosphorylation of Akt in neutrophil-like dHL-60 cells. (a) dHL-60 cells $\left(5 \times 10^{6}\right)$ were exposed to RES $(3 \mu \mathrm{M})$ for $1 \mathrm{~h}$, and then stimulated with GM-CSF $(5 \mathrm{ng} / \mathrm{mL})$ for $30 \mathrm{~min}$. (b) The protein levels were quantitated by densitometry. B, PBS-added and unstimulated cells; C, PBS-added and GM-CSF-stimulated cells; RES, RES-added and GM-CSF-stimulated cells. Data are shown as the mean \pm SEM of three independent experiments. ${ }^{*} p<0.05$ vs. the PBS-added and GM-CSF-stimulated cells.

\subsection{RES Decreases Phosphorylation of NF- $\mathrm{B}$ in Neutrophil-like dHL-60 Cells}

To understand the regulatory mechanism of OSM reduction by RES, we exposed neutrophil-like dHL-60 cells to RES $(3 \mu \mathrm{M})$ for $1 \mathrm{~h}$. Similar to a previous report [14], GM$\mathrm{CSF}$ treatment for $1 \mathrm{~h}$ led to increased NF-kB phosphorylation (Figure 6). However, a decrease in NF- $\mathrm{kB}$ phosphorylation resulted from the exposure to RES (Figure 6). RES alone did not affect NF-KB phosphorylation (Figure S2e,f).

(a)

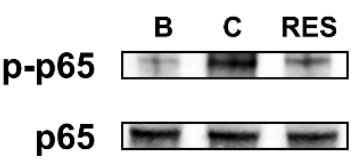

(b)

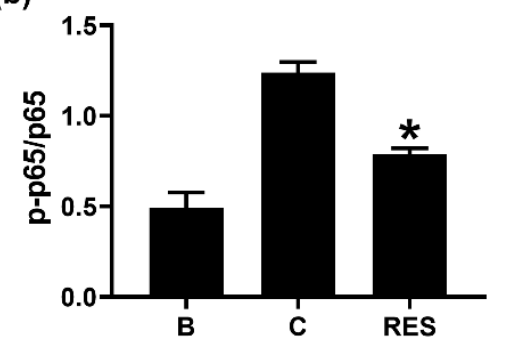

Figure 6. Effects of RES on the phosphorylation of NF-kB in neutrophil-like dHL-60 cells. (a) dHL-60 cells $\left(5 \times 10^{6}\right)$ were exposed to RES $(3 \mu \mathrm{M})$ for $1 \mathrm{~h}$, and then stimulated with GM-CSF $(5 \mathrm{ng} / \mathrm{mL})$ for $1 \mathrm{~h}$. (b) The protein levels were quantitated by densitometry. B, PBS-added and unstimulated cells; C, PBS-added and GM-CSF-stimulated cells; RES, RES-added and GM-CSF-stimulated cells. Data are shown as the mean \pm SEM of three independent experiments. ${ }^{*} p<0.05$ vs. the PBS-added and GM-CSF-stimulated cells.

\section{Discussion}

Numerous studies have reported that increased OSM levels are detected in inflammatory diseases, including chronic rhinosinusitis and asthma [12,43,44]. Ma et al. [45] suggested that GM-CSF stimulation induces elevated OSM mRNA expression. Moreover, many studies reported that elevation of OSM resulted from stimulation by GM-CSF in human neutrophils [12,26,46,47]. Similar to our previous report [14], the results of the present study demonstrated that exposure of neutrophil-like dHL-60 cells to GM-CSF results in increased OSM production and mRNA expression (Figures $2 \mathrm{a}$ and 3 ). The increases in OSM production and mRNA expression were attenuated by addition of RES (Figures $2 \mathrm{a}$ and 3). Treatment with OSM protein in the nasal cavity led to the infiltration of inflammatory cells and upregulation of inflammatory cytokines and chemokines in a murine model [48]. Modur and colleagues [49] suggested that skin inflammation is increased by hypodermic injection of OSM protein in mice. It was reported [50] that lung inflammation resulted from hyperexpression of OSM in a murine model. High levels of OSM mRNA and protein were exhibited in patients with asthma, whereas no OSM was shown in control subjects [44]. Furthermore, an OSM-deficiency and neutralizing antibody treatment decreased colon in- 
flammation [3]. Thus, we presuppose that RES might be advantageous for use in preventing and/or treating inflammatory diseases through blockade of OSM.

It is widely known that the PI3K/AKT signal pathway plays a pivotal role in inflammatory reactions [15-18]. NF- $\mathrm{KB}$ is a well-known transcription factor of inflammatory responses [19]. It was reported that OSM production is mediated by PI3K/Akt/NF- KB signal pathway in osteoblasts [19]. Our previous report also confirmed a dependency of the PI3K/Akt/NF-kB signal pathway on OSM production in neutrophil-like dHL-60 cells [25]. Treatment with PI3K inhibitor decreased the mRNA expression and protein levels of various inflammatory cytokines, such as IL- $1 \beta$, IL-6, and tumor necrosis factor (TNF)- $\alpha$, in nucleus pulposus cells [51]. In addition, blockade of PI3K/Akt signal pathway resulted in reduction of osteoarthritis in mice [52]. Administration of well-known PI3K inhibitors, including wortmannin, LY-294002, and IC87114, suppressed airway hyperresponsiveness and inflammation in a murine model of asthma $[53,54]$. Furthermore, treatment with an Akt inhibitor (deguelin) downregulated airway inflammation in asthmatic mice [55]. NF- $\mathrm{kB}$ inhibition also attenuated airway inflammation and hyperresponsiveness in ovalbumininduced asthma model $[55,56]$. Our results showed that RES treatment induced decreases in phosphorylation of PI3K, Akt, and NF- $\mathrm{KB}$ (Figures 4-6). Thus, we presume that decrease of OSM by RES might be at least partly controlled by PI3K/Akt/NF-KB signaling pathway in neutrophil-like dHL-60 cells.

Cardiovascular and cerebrovascular disorders, together with cancers, constitute the most important causes of death in Europe, the USA, and most Asian countries. It was suggested that RES exerts beneficial effects on cardiovascular diseases [57]. Thaung Zaw et al. [58] reported that RES enhances cerebrovascular function in postmenopausal women. Hence, we assume that RES may be helpful for many people to prevent and/or treat inflammatory diseases, as well as cardiovascular and cerebrovascular disorders, in Europe, USA, and most Asian countries. Therefore, RES could reduce duplication of medication in inflammatory disease patients with cardiovascular and cerebrovascular disorders.

Lastly, no toxic effect was shown in rats that were administered $300 \mathrm{mg} / \mathrm{kg}$ of RES daily for 4 weeks [59]. Here, we utilized $3 \mu \mathrm{M}$ of RES (approximately $0.684 \mathrm{mg} / \mathrm{kg}$ ). Hence, we could assume that RES may not be toxic to humans at concentration of $3 \mu \mathrm{M}$.

\section{Conclusions}

In conclusion, we showed that RES repressed OSM production via downregulation of PI3K/Akt/NF-KB signal cascade in neutrophil-like dHL-60 cells (Figure 7). The results of the present study suggest that RES may be a useful drug target for inflammatory disorders treatment.

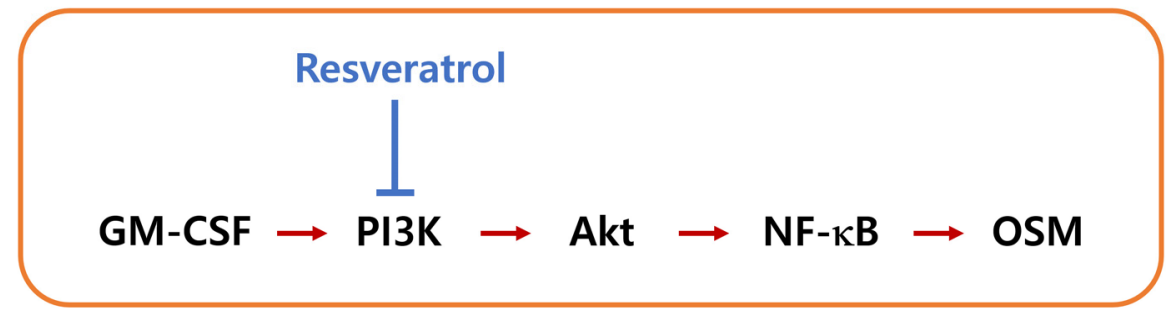

Figure 7. A schematic diagram of the proposed inhibition of OSM by RES.

Supplementary Materials: The following are available online at https:/ / www.mdpi.com/article/ 10.3390 / cimb44020037/s1. Figure S1: Effects of RES on the production and mRNA expression of OSM in neutrophil-like dHL-60 cells. Figure S2: Effects of RES on the phosphorylation of PI3K, Akt, and NF- $\mathrm{KB}$ in neutrophil-like dHL-60 cells.

Author Contributions: Conceptualization, H.-J.P. and P.-D.M.; investigation, N.-R.H. and P.-D.M.; writing-original draft preparation, N.-R.H. and P.-D.M.; funding acquisition, N.-R.H. All authors have read and agreed to the published version of the manuscript. 
Funding: This work was supported by the National Research Foundation of Korea (NRF) grant funded by the Korea government (MSIT) (No. 2020R1A5A2019413).

Institutional Review Board Statement: Not applicable.

Informed Consent Statement: Not applicable.

Data Availability Statement: Data is contained within the article.

Conflicts of Interest: The authors declare no conflict of interest.

\section{References}

1. Zarling, J.M.; Shoyab, M.; Marquardt, H.; Hanson, M.B.; Lioubin, M.N.; Todaro, G.J. Oncostatin M: A growth regulator produced by differentiated histiocytic lymphoma cells. Proc. Natl. Acad. Sci. USA 1986, 83, 9739-9743. [CrossRef]

2. Yang, X.; Shao, C.; Duan, L.; Hou, X.; Huang, Y.; Gao, L.; Zong, C.; Liu, W.; Jiang, J.; Ye, F.; et al. Oncostatin M promotes hepatic progenitor cell activation and hepatocarcinogenesis via macrophage-derived tumor necrosis factor- $\alpha$. Cancer Lett. 2021, 517, 46-54. [CrossRef]

3. West, N.R.; Hegazy, A.N.; Owens, B.M.J.; Bullers, S.J.; Linggi, B.; Buonocore, S.; Coccia, M.; Görtz, D.; This, S.; Stockenhuber, K.; et al. Oncostatin $\mathrm{M}$ drives intestinal inflammation and predicts response to tumor necrosis factor-neutralizing therapy in patients with inflammatory bowel disease. Nat. Med. 2017, 23, 579-589. [CrossRef] [PubMed]

4. $\quad$ Reid, J.; Zamuner, S.; Edwards, K.; Rumley, S.A.; Nevin, K.; Feeney, M.; Zecchin, C.; Fernando, D.; Wisniacki, N. In vivo affinity and target engagement in skin and blood in a first-time-in-human study of an anti-oncostatin M monoclonal antibody. Br. J. Clin. Pharmacol. 2018, 84, 2280-2291. [CrossRef] [PubMed]

5. Wang, H.; Lei, L.; Hu, J.; Li, Y. Oncostatin M upregulates Livin to promote keratinocyte proliferation and survival via ERK and STAT3 signalling pathways. Exp. Physiol. 2020, 105, 1151-1158. [CrossRef]

6. Zoaiter, M.; Nasser, R.; Hage-Sleiman, R.; Abdel-Sater, F.; Badran, B.; Zeaiter, Z. Helicobacter pylori outer membrane vesicles induce expression and secretion of oncostatin M in AGS gastric cancer cells. Braz. J. Microbiol. 2021, 52, 1057-1066. [CrossRef] [PubMed]

7. Mashimo, K.; Usui-Ouchi, A.; Ito, Y.; Wakasa-Arai, R.; Yokoi, N.; Kawasaki, S.; Murakami, A.; Matsuda, A.; Ebihara, N. Role of oncostatin $\mathrm{M}$ in the pathogenesis of vernal keratoconjunctivitis: Focus on tissue remodeling. Jpn. J. Ophthalmol. 2021, 65, 144-153. [CrossRef] [PubMed]

8. Kubin, T.; Pöling, J.; Kostin, S.; Gajawada, P.; Hein, S.; Rees, W.; Wietelmann, A.; Tanaka, M.; Lörchner, H.; Schimanski, S.; et al. Oncostatin M is a major mediator of cardiomyocyte dedifferentiation and remodeling. Cell Stem Cell 2011, 9, 420-432. [CrossRef] [PubMed]

9. Stephens, J.M.; Elks, C.M. Oncostatin M: Potential Implications for Malignancy and Metabolism. Curr. Pharm. Des. 2017, 23, 3645-3657. [CrossRef]

10. Garcia, J.P.; Utomo, L.; Rudnik-Jansen, I.; Du, J.; Zuithoff, N.; Krouwels, A.; van Osch, G.; Creemers, L.B. Association between Oncostatin M Expression and Inflammatory Phenotype in Experimental Arthritis Models and Osteoarthritis Patients. Cells 2021, 10, 508. [CrossRef]

11. Kang, H.J.; Kang, J.S.; Lee, S.H.; Hwang, S.J.; Chae, S.W.; Woo, J.S.; Lee, H.M. Upregulation of oncostatin m in allergic rhinitis. Laryngoscope 2005, 115, 2213-2216. [CrossRef]

12. Pothoven, K.L.; Norton, J.E.; Suh, L.A.; Carter, R.G.; Harris, K.E.; Biyasheva, A.; Welch, K.; Shintani-Smith, S.; Conley, D.B.; Liu, M.C.; et al. Neutrophils are a major source of the epithelial barrier disrupting cytokine oncostatin $\mathrm{M}$ in patients with mucosal airways disease. J. Allergy Clin. Immunol. 2017, 139, 1966-1978. [CrossRef]

13. Liu, J.; Zhong, Y.; Liu, H.; Yang, H.; Lu, P.; Shi, Y.; Wang, X.; Zheng, W.; Yu, X.; Xu, Y.; et al. Oncostatin M sensitizes keratinocytes to UVB-induced inflammation via GSDME-mediated pyroptosis. J. Dermatol. Sci. 2021, 104, 95-103. [CrossRef]

14. Han, N.R.; Ko, S.G.; Park, H.J.; Moon, P.D. Dexamethasone Attenuates Oncostatin M Production Via Suppressing of PI3K/Akt/NFKB Signaling in Neutrophil-Like Differentiated HL-60 Cells. Molecules 2022, 27, 129. [CrossRef] [PubMed]

15. Han, W.; Xiong, Y.; Li, Y.; Fang, W.; Ma, Y.; Liu, L.; Li, F.; Zhu, X. Anti-arthritic effects of clematichinenoside (AR-6) on PI3K/Akt signaling pathway and TNF- $\alpha$ associated with collagen-induced arthritis. Pharm. Biol. 2013, 51, 13-22. [CrossRef]

16. Yang, W.H.; Tsai, C.H.; Fong, Y.C.; Huang, Y.L.; Wang, S.J.; Chang, Y.S.; Tang, C.H. Leptin induces oncostatin M production in osteoblasts by downregulating miR-93 through the Akt signaling pathway. Int. J. Mol. Sci. 2014, 15, 15778-15790. [CrossRef] [PubMed]

17. Chang, F.; Lee, J.T.; Navolanic, P.M.; Steelman, L.S.; Shelton, J.G.; Blalock, W.L.; Franklin, R.A.; McCubrey, J.A. Involvement of PI3K/Akt pathway in cell cycle progression, apoptosis, and neoplastic transformation: A target for cancer chemotherapy. Leukemia 2003, 17, 590-603. [CrossRef] [PubMed]

18. Lv, B.; Deng, L.; Xie, T.; Wei, X.; Liu, X.; Tan, W.; Wang, X.; Gao, X. Evaluation of the anti-inflammatory and antioxidant pharmcodynamic compoents of naoxintong capsules as a basis of broad spectrum effects. Pharm. Biol. 2021, 59, $242-251$. [CrossRef] [PubMed]

19. Su, C.M.; Lee, W.L.; Hsu, C.J.; Lu, T.T.; Wang, L.H.; Xu, G.H.; Tang, C.H. Adiponectin Induces Oncostatin M Expression in Osteoblasts through the PI3K/Akt Signaling Pathway. Int. J. Mol. Sci. 2016, 17, 29. [CrossRef] 
20. Li, T.; Tan, Y.; Ouyang, S.; He, J.; Liu, L. Resveratrol protects against myocardial ischemia-reperfusion injury via attenuating ferroptosis. Gene 2022, 808, 145968. [CrossRef] [PubMed]

21. Moon, P.D.; Han, N.R.; Lee, J.S.; Jee, H.W.; Kim, J.H.; Kim, H.M.; Jeong, H.J. Effects of Resveratrol on Thymic Stromal Lymphopoietin Expression in Mast Cells. Medicina 2021, 57, 21. [CrossRef] [PubMed]

22. Lin, M.; Yao, W.; Xiao, Y.; Dong, Z.; Huang, W.; Zhang, F.; Zhou, X.; Liang, M. Resveratrol-modified mesoporous silica nanoparticle for tumor-targeted therapy of gastric cancer. Bioengineered 2021, 12, 6343-6353. [CrossRef] [PubMed]

23. Niu, W.; Wang, H.; Wang, B.; Mao, X.; Du, M. Resveratrol improves muscle regeneration in obese mice through enhancing mitochondrial biogenesis. J. Nutr. Biochem. 2021, 98, 108804. [CrossRef] [PubMed]

24. Siddiqui, M.A.; Akhter, J.; Aarzoo; Junaid Bashir, D.; Manzoor, S.; Rastogi, S.; Arora, I.; Aggarwal, N.B.; Samim, M. Resveratrol loaded nanoparticles attenuate cognitive impairment and inflammatory markers in PTZ-induced kindled mice. Int. Immunopharmacol. 2021, 101, 108287. [CrossRef] [PubMed]

25. Ruan, X.; Deng, X.; Tan, M.; Wang, Y.; Hu, J.; Sun, Y.; Yu, C.; Zhang, M.; Jiang, N.; Jiang, R. Effect of resveratrol on the biofilm formation and physiological properties of avian pathogenic Escherichia coli. J. Proteomics 2021, 249, 104357. [CrossRef]

26. Elbjeirami, W.M.; Donnachie, E.M.; Burns, A.R.; Smith, C.W. Endothelium-derived GM-CSF influences expression of oncostatin M. Am. J. Physiol. Cell Physiol. 2011, 301, C947-C953. [CrossRef]

27. Moon, P.D.; Lee, J.S.; Kim, H.Y.; Han, N.R.; Kang, I.; Kim, H.M.; Jeong, H.J. Heat-treated Lactobacillus plantarum increases the immune responses through activation of natural killer cells and macrophages on in vivo and in vitro models. J. Med. Microbiol. 2019, 68, 467-474. [CrossRef]

28. Alghamdi, Y.S.; Saleh, O.M.; Alqadri, N.; Mashraqi, M.M.; Bahattab, O.; Awad, N.S. Effect of Ducrosia flabellifolia and Savignya parviflora Extracts on Inhibition of Human Colon and Prostate Cancer Cell Lines. Curr. Issues Mol. Biol. 2021, 43, 1518-1528. [CrossRef] [PubMed]

29. Insuan, O.; Janchai, P.; Thongchuai, B.; Chaiwongsa, R.; Khamchun, S.; Saoin, S.; Insuan, W.; Pothacharoen, P.; Apiwatanapiwat, W.; Boondaeng, A.; et al. Anti-Inflammatory Effect of Pineapple Rhizome Bromelain through Downregulation of the NF-B- and MAPKs-Signaling Pathways in Lipopolysaccharide (LPS)-Stimulated RAW264.7 Cells. Curr. Issues Mol. Biol. 2021, 43, 93-106. [CrossRef] [PubMed]

30. Han, N.R.; Ko, S.G.; Moon, P.D.; Park, H.J. Chloroquine attenuates thymic stromal lymphopoietin production via suppressing caspase-1 signaling in mast cells. Biomed. Pharmacother. 2021, 141, 111835. [CrossRef] [PubMed]

31. Moon, P.D.; Han, N.R.; Kim, H.M.; Jeong, H.J. High-Fat Diet Exacerbates Dermatitis through Up-Regulation of TSLP. J. Investig. Dermatol. 2019, 139, 1198-1201. [CrossRef] [PubMed]

32. Han, N.R.; Ko, S.G.; Moon, P.D.; Park, H.J. Ginsenoside Rg3 attenuates skin disorders via down-regulation of MDM2/HIF1 $\alpha$ signaling pathway. J. Ginseng Res. 2021, 45, 610-616. [CrossRef] [PubMed]

33. Han, N.R.; Kim, H.J.; Lee, J.S.; Kim, H.Y.; Moon, P.D.; Kim, H.M.; Jeong, H.J. The immune-enhancing effect of anthocyaninfucoidan nanocomplex in RAW264.7 macrophages and cyclophosphamide-induced immunosuppressed mice. J. Food Biochem. 2021, 45, e13631. [CrossRef] [PubMed]

34. Moon, P.D.; Han, N.R.; Lee, J.S.; Kim, H.M.; Jeong, H.J. p-coumaric acid, an active ingredient of Panax ginseng, ameliolates atopic dermatitis-like skin lesions through inhibition of thymic stromal lymphopoietin in mice. J. Ginseng Res. 2021, 45, 176-182. [CrossRef]

35. Han, N.R.; Kim, H.Y.; Kang, S.; Kim, M.H.; Yoon, K.W.; Moon, P.D.; Kim, H.M.; Jeong, H.J. Chrysophanol, an anthraquinone from AST2017-01, possesses the anti-proliferative effect through increasing p53 protein levels in human mast cells. Inflamm. Res. 2019, 68, 569-579. [CrossRef]

36. Han, N.R.; Moon, P.D.; Kim, H.M.; Jeong, H.J. TSLP Exacerbates Septic Inflammation via Murine Double Minute 2 (MDM2) Signaling Pathway. J. Clin. Med. 2019, 8, 1350. [CrossRef]

37. Alamir, A.H.; Patil, S. Allicin Could Potentially Alleviate Oral Cancer Pain by Inhibiting “Pain Mediators" TNF-alpha, IL-8, and Endothelin. Curr. Issues Mol. Biol. 2021, 43, 187-196. [CrossRef] [PubMed]

38. Kang, M.H.; Jang, G.Y.; Ji, Y.-J.; Lee, J.H.; Choi, S.J.; Hyun, T.K.; Kim, H.D. Antioxidant and Anti-Melanogenic Activities of Heat-Treated Licorice (Wongam, Glycyrrhiza glabra $\times$ G. uralensis) Extract. Curr. Issues Mol. Biol. 2021, 43, 1171-1187. [CrossRef] [PubMed]

39. Moon, P.D.; Han, N.R.; Lee, J.S.; Kim, H.M.; Jeong, H.J. Ursolic acid downregulates thymic stromal lymphopoietin through the blockade of intracellular calcium/caspase-1/NF-kB signaling cascade in HMC-1 cells. Int. J. Mol. Med. 2019, 43, 2252-2258. [CrossRef]

40. Moon, P.D.; Han, N.R.; Lee, J.S.; Hong, S.; Yoo, M.S.; Kim, H.J.; Kim, J.H.; Kang, S.; Jee, H.W.; Kim, H.M.; et al. Use of Physcion to Improve Atopic Dermatitis-Like Skin Lesions through Blocking of Thymic Stromal Lymphopoietin. Molecules 2019, 24,1484 [CrossRef] [PubMed]

41. Han, N.R.; Han, S.J.; Moon, P.D.; Hong, S.; Kim, H.; Li, Y.H.; Kim, H.M.; Jeong, H.J. Effect of dexamethasone injection into Zusanli (ST 36) acupoint on ovalbumin-induced allergic rhinitis. J. Tradit. Chin. Med. 2019, 39, 307-314.

42. Iannucci, J.; Sen, A.; Grammas, P. Isoform-Specific Effects of Apolipoprotein E on Markers of Inflammation and Toxicity in Brain Glia and Neuronal Cells In Vitro. Curr. Issues Mol. Biol. 2021, 43, 215-225. [CrossRef] 
43. Pothoven, K.L.; Norton, J.E.; Hulse, K.E.; Suh, L.A.; Carter, R.G.; Rocci, E.; Harris, K.E.; Shintani-Smith, S.; Conley, D.B.; Chandra, R.K.; et al. Oncostatin M promotes mucosal epithelial barrier dysfunction, and its expression is increased in patients with eosinophilic mucosal disease. J. Allergy Clin. Immunol. 2015, 136, 737-746.e4. [CrossRef]

44. Simpson, J.L.; Baines, K.J.; Boyle, M.J.; Scott, R.J.; Gibson, P.G. Oncostatin M (OSM) is increased in asthma with incompletely reversible airflow obstruction. Exp. Lung Res. 2009, 35, 781-794. [CrossRef]

45. Ma, Y.; Streiff, R.J.; Liu, J.; Spence, M.J.; Vestal, R.E. Cloning and characterization of human oncostatin M promoter. Nucleic Acids Res. 1999, 27, 4649-4657. [CrossRef] [PubMed]

46. Cross, A.; Edwards, S.W.; Bucknall, R.C.; Moots, R.J. Secretion of oncostatin M by neutrophils in rheumatoid arthritis. Arthritis Rheum. 2004, 50, 1430-1436. [CrossRef] [PubMed]

47. Grenier, A.; Dehoux, M.; Boutten, A.; Arce-Vicioso, M.; Durand, G.; Gougerot-Pocidalo, M.A.; Chollet-Martin, S. Oncostatin M production and regulation by human polymorphonuclear neutrophils. Blood 1999, 93, 1413-1421. [CrossRef]

48. Mozaffarian, A.; Brewer, A.W.; Trueblood, E.S.; Luzina, I.G.; Todd, N.W.; Atamas, S.P.; Arnett, H.A. Mechanisms of oncostatin M-induced pulmonary inflammation and fibrosis. J. Immunol. 2008, 181, 7243-7253. [CrossRef]

49. Modur, V.; Feldhaus, M.J.; Weyrich, A.S.; Jicha, D.L.; Prescott, S.M.; Zimmerman, G.A.; McIntyre, T.M. Oncostatin M is a proinflammatory mediator. In vivo effects correlate with endothelial cell expression of inflammatory cytokines and adhesion molecules. J. Clin. Investig. 1997, 100, 158-168. [CrossRef]

50. Botelho, F.; Dubey, A.; Ayaub, E.A.; Park, R.; Yip, A.; Humbles, A.; Kolbeck, R.; Richards, C.D. IL-33 Mediates Lung Inflammation by the IL-6-Type Cytokine Oncostatin M. Mediators Inflamm. 2020, 2020, 4087315. [CrossRef]

51. He, S.; Fu, Y.; Yan, B.; Tan, H.; Li, H.; Li, J.; Huang, D.; Huang, Z.; Lai, J.; Feng, H.; et al. Curcumol Alleviates the Inflammation of Nucleus Pulposus Cells via the PI3K/Akt/NF-кB Signaling Pathway and Delays Intervertebral Disk Degeneration. World Neurosurg. 2021, 155, e402-e411. [CrossRef]

52. Wang, L.; Tang, X.; Li, S. Propofol promotes migration, alleviates inflammation, and apoptosis of lipopolysaccharide-induced human pulmonary microvascular endothelial cells by activating PI3K/AKT signaling pathway via upregulating APOM expression. Drug Dev. Res. 2021. [CrossRef]

53. Kwak, Y.G.; Song, C.H.; Yi, H.K.; Hwang, P.H.; Kim, J.S.; Lee, K.S.; Lee, Y.C. Involvement of PTEN in airway hyperresponsiveness and inflammation in bronchial asthma. J. Clin. Investig. 2003, 111, 1083-1092. [CrossRef]

54. Lee, K.S.; Lee, H.K.; Hayflick, J.S.; Lee, Y.C.; Puri, K.D. Inhibition of phosphoinositide 3-kinase delta attenuates allergic airway inflammation and hyperresponsiveness in murine asthma model. FASEB J. 2006, 20, 455-465. [CrossRef] [PubMed]

55. Bao, Z.; Zhang, P.; Yao, Y.; Lu, G.; Tong, Z.; Yan, B.; Tu, L.; Yang, G.; Zhou, J. Deguelin Attenuates Allergic Airway Inflammation via Inhibition of NF-kb Pathway in Mice. Int. J. Biol. Sci. 2017, 13, 492-504. [CrossRef] [PubMed]

56. El-Hashim, A.Z.; Renno, W.M.; Abduo, H.T.; Jaffal, S.M.; Akhtar, S.; Benter, I.F. Effect of inhibition of the ubiquitin-proteasomesystem and $\mathrm{I} \kappa \mathrm{B}$ kinase on airway inflammation and hyperresponsiveness in a murine model of asthma. Int. J. Immunopathol. Pharmacol. 2011, 24, 33-42. [CrossRef] [PubMed]

57. Gal, R.; Deres, L.; Toth, K.; Halmosi, R.; Habon, T. The Effect of Resveratrol on the Cardiovascular System from Molecular Mechanisms to Clinical Results. Int. J. Mol. Sci. 2021, 22, 10152. [CrossRef]

58. Thaung Zaw, J.J.; Howe, P.R.; Wong, R.H. Long-term effects of resveratrol on cognition, cerebrovascular function and cardiometabolic markers in postmenopausal women: A 24-month randomised, double-blind, placebo-controlled, crossover study. Clin. Nutr. 2021, 40, 820-829. [CrossRef]

59. Crowell, J.A.; Korytko, P.J.; Morrissey, R.L.; Booth, T.D.; Levine, B.S. Resveratrol-associated renal toxicity. Toxicol. Sci. 2004, 82, 614-619. [CrossRef] 